OPEN ACCESS

ISSN 2541-2841 (online) ISSN 2302-6790 (print)

Edited by Sitti Murni Kaddi

${ }^{*}$ Correspondence: Rochmaniah ainur@umsida.ac.id

Citation:

Rochmaniah, A., Ridwanti, A. E., Ulfiyah, A., Octaviani, R. S.,

Oktaviana, A. D. (2021)

Komunikasi Pemasaran dalam Meningkatkan Okupansi Kamar di Hotel Reddoorz Pada Masa Pandemi Covid-19, Kanal, 9(2). Doi:10.21070/kanal.v9i2.1230

\section{Marketing Communication in Increasing Room Occupancy at Reddoorsz Hotels During the Covid-19 Pandemic}

\section{Komunikasi Pemasaran dalam Meningkatkan Okupansi Kamar di Hotel Reddoorsz pada Masa Pandemi Covid -19}

\author{
Ainur Rochmaniah ${ }^{1 *}$, Adella Eka Ridwanti², Asiyatul Ulfiyah ${ }^{3}$, Rachma Sari Octaviani ${ }^{4}$, Ayu \\ Diah Oktaviana ${ }^{5}$ \\ 1,2,3,4,5 Program Studi Ilmu Komunikasi Universitas Muhammadiyah Sidoarjo
}

\begin{abstract}
The Covid -19 pandemic has significantly decreased the occupancy of the RedDoorz Syariah Buduran Sidoarjo Hotel rooms. The objective is to describe the marketing communication strategy used by the RedDoorz Syariah Buduran Hotel in increasing room occupancy. The study used a qualitative research method at the RedDoorz Buduran Hotel in March-August 2020. The information in this study was the hotel manager which was equipped with 3 people and 5 hotel visitors, with a purposive sampling technique which the criteria of hotel managers dan service staff. Observation data observation techniques, open interviews, and documentation. The results show that the RedDoorz Syariah Buduran hotel has carried out digital advertising through social media such as media (Instagram, website and Twitter) andTV advertising (youtube), sales promotion through the distribution of discount vouchers to visitors and holding local scale events, as well as conducting communication through the public relations division by inviting the surrounding community at the hotel anniversary event. The marketing communication strategies that are carried out are integrated with each other, so as to increase the number of visitors during a pandemic.

Keywords: Marketing Communicatio, Hotel, Pandemic.
\end{abstract}

\begin{abstract}
Abstrak
Pandemi Covid -19 membuat okupansi kamar Hotel RedDoorz Syariah Buduran Sidoarjo turun signifikan. Tujuan penelitian adalah untuk mendeskripsikan strategi komunikasi pemasaran yang digunakan Hotel RedDoorz Syariah Buduran dalam meningkatkan okupansi kamar. Penelitian ini menggunakan metode penelitian kualitatif di Hotel RedDoorz Buduran pada bulabn Maret-Agustus 2020. Informan dalam penelitian ini adalah pengelola hotel yang berjumlah 3 orang dan 5 orang pengunjung hotel, dengan teknik purposive sampling dengan kriteria pengelolkah hotel dan staf pelayanan. Teknik pegumpulan data menggunakan observasi, wawan-
\end{abstract}


cara terbuka, dan dokumentasii. Hasil penelitian menunjukkan bahwa hotel RedDoorz Syariah Buduran telah melakukan periklanan secara digital melalui media sosial seperti media (instagram, website dan twitter) dan iklan TV (youtube), promosi penjualan melalui pembagian voucher diskon kepada pengunjung dan mengadakan event-event skala lokal, serta melakukan komunikasi melalui divisi public relation dengan mengudang masyarakat sekitar pada saat acara ulang tahun hotel. Strategi komunikasi pemasaran yang dilakukan terintegrasi satu sama lain, sehingga dapat meningkatkan jumlah pengunjung di masa pandemi.

Kata Kunci: Komunikasi Pemasaran, Hotel, Pandemi

\section{PENDAHULUAN}

Pandemi Covid-19 terjadi hampir di seluruh penjuru dunia. Covid-19 (Coronavirus Diseases 2019) adalah penyakit jenis baru yang belum pernah diidentifikasi pada manusia. Tanda dan gejala umum infeksi Covid-19 antara lain gangguan pernapasan akut seperti demam, batuk, dan sesak napas. Orang yang positif Covid-19 nantinya akan menjalani masa inkubasi rata-rata 5 - 6 hari dengan masa inkubasi terpanjang 14 hari. Dengan adanya virus Covid-19 di Indonesia saat ini berdampak pada tingkat hidup dan pendapatan masyarakat. Dampak ini juga terjadi diberbagai bidang industri seperti sosial, ekonomi, pariwisata, dan pendidikan sehingga pemerintah menetapkan peraturan terkait PSBB untuk mencegah penyebaran virus Covid-19. Peraturan Pemerintah Republik Indonesia Nomor 21 Tahun 2020 menetapkan bahwa PSBB (Pembatasan Sosial Berskala Besar) dalam Rangka Percepatan Penanganan Covid-19 yang juga ditetapkan pada 31 Maret 2020 meliputi peliburan sekolah dan tempat kerja, pembatasan kegiatan keagamaan, serta pembatasan kegiatan di tempat atau fasilitas umum.PSBB ini ditetapkan oleh Menteri Kesehatan kepada Pemerintah Daerah dengan memerhatikan ketentuan yang diatur dalam UU Nomor 6 Tahun 2018 tentang Kekarantinaan Kesehatan.

Industri pariwisata, terutama yang bergerak dalam bidang persewaan properti seperti perhotelan adalah salah satu kegiatan industri yang terkena dampak Covid-19 tersebut. Adanya himbauan dari pemerintah untuk tetap berada di rumah saja mengakibatkan banyak industri hotel ini mengalami penurunan okupansi (tingkat hunian kamar) yang cukup signifikan. Salah satunya adalah Hotel RedDoorz Syariah Buduran yang terletak di Wadungasih, Sidoarjo. Hotel RedDoorz Syariah Buduran adalah salah satu bangunan milik koperasi bulog yang berdiri sekitar bulan November 2018.

Pada awalnya tempat tersebut merupakan tanah kosong milik koperasi bulog yang kemudian dibangun Hotel RedDoorz Syariah Buduran dengan tujuan untuk menciptakan lapangan pekerjaan bagi warga lingkungan setempat. Tempat tersebut dipilih karena lokasinya yang dekat dengan pabrik, puskesmas, serta kantor polisi yang seharusnya tidak mengalami penurunan okupansi kamar hotel karena mengingat tempat sekitar yang cukup ramai orang. Target pemasaran yang dituju oleh Hotel RedDoorz Syariah Buduran sendiri adalah orang umum, namun sebagi- an besar pengunjung hotel tersebut berasal dari luar kota atau pengunjung dari pabrik sekitar. Hotel RedDoorz Syariah Buduran saat ini memiliki delapan orang karyawan. Masingmasing diantaranya adalah tiga orang sebagai security, tiga orang sebagai house keeping, satu orang sebagai resepsionis, serta satu orang sebagai manager. Pada masa pandemi seperti ini membuat tingkat okupansi Hotel RedDoorz Syariah Buduran turun drastis yakni hanya dapat mencapai target 3 4 kamar saja per-hari.

Hal ini terjadi karena adanya himbauan dari pemerintah untuk tetap di rumah saja apabila tidak ada keperluan yang mendesak dan juga kebijakan perusahaan yang melakukan pengurangan tenaga kerja, serta banyak pabrik yang tutup menjadi faktor utama dalam menurunnya jumlah okupansi Hotel RedDoorz Syariah Buduran. Terlihat pada Tabel 1 yang menunjukkan jumlah okupansi Hotel RedDoorz Syariah Buduran dari 6 bulan sebelum pandemi Covid-19 yaitu bulan September - Februari 2019 hingga 6 bulan setelah pandemi yaitu bulan Maret - Agustus 2020.

Dapat diamati dari tabel tersebut bahwa jumlah okupansi sebelum masa pandemi Covid-19 berjalan normal dan cenderung mengalami peningkatan hingga sesudah pandemi Covid-19 yang mengalami penurunan signifikan dalamjumlah okupansi kamar hotel.

Tabel 1.Okupansi Kamar Hotel RedDoorz Syariah Buduran September 2019 - Agustus 2020

\begin{tabular}{|c|c|c|}
\hline Bulan & $\underline{2019}$ & $\underline{2020}$ \\
\hline September & 246 kamar & \\
\hline Oktober & 282 kamar & \\
\hline November & 277 kamar & \\
\hline Desember & 319 kamar & \\
\hline Januari & & 276 kamar \\
\hline Pebruari & & 245 kamar \\
\hline Maret & & 215 kamar \\
\hline April & & 137 kamar \\
\hline Mei & & 102 kamar \\
\hline
\end{tabular}




\section{Juni}

Juli Agustus

\section{6 kamar}

130 kamar

78 kamar

Dari tabel 1 dapat dilihat terjadi penurunan okupansi kamar yang sangat signifikan dari bulan September 2019 sampai dengan Agustus 2020. Hal ini sesuai dengan hasil penelitian dari Lanang Diayudha (2020), bahwa (1) Terjadi penurunan okupansi secara signifikan dalam kurun waktu seminggu dari biasanya dan (2) Terjadi penurunan atas permintaan penyediaan ruang pertemuan, produksi, makanan, dan minuman yang terjadi di restoran hotel yang mengakibatkan kondisi keuangan hotel terganggu.Penurunan okupansi ini kemudian memunculkan inisiatif dari manajemen Hotel RedDoorz Syariah Buduran untuk melakukan strategi komunikasi pemasaran. William J. Stanton (2007) menyatakan bahwa pemasaran merupakan suatu sistem keseluruhan dari kegiatan-kegiatan bisnis yang ditujukan untuk merencanakan, menentukan harga, mempromosikan, dan mendistribusikan barang dan jasa yang memuaskan kebutuhan pembeli potensial.

Amir Purba (2006), mengutip pendapat William F. Nickles bahwa komunikasi pemasaran yaitu proses pertukaran informasi yang dilakukan secara persuasif sehingga proses pemasaran berjalan secara efektif dan efisien.

Dari beberapa pendapat para ahli di atas dapat di simpulkan bahwa komunikasi pemasaran adalah proses pertukaran informasi yang dilakukan untuk mempengaruhi konsumen agar mereka tertarik dengan produk yang kita tawarkan atau pasarkan. Hal tersebut bisa dilakukan dengan cara berinteraksi secara langsung dengan calon konsumen, dengan begitu perusahaan dapat memahami kebutuhan pasar, sehingga dapat menimbulkan proses transaksi jual beli yang didalamnya terjadi proses tawar menawar yang kemudian menimbulkan kepercayaan dan loyalitas konsumen terhadap produk perusahaan tersebut. Bentuk-bentuk komunikasi pemasaran menurut Assauri (2013) adalah:

a) Periklanan (advertising). Periklanan dianggap sebagai manajemen citra yang bertujuan untuk menciptakan dan memelihara citra dan makna dalam benak konsumen. Faktor utama kunci dari periklanan adalah bahwa setiap iklan harus bisa menarik perhatian calon konsumen terhadap produk atau jasa yang ditawarkan oleh perusahaan. Bentuk promosi yang bisa dilakukan adalah bisa dalam bentuk tayangan, gambar atau kata-kata yang bisa di tuangkan melalui media luar ruangan seperti banner, pamflet, spanduk dan baliho. Atau bisa juga melalui media massa seperti internet, media sosial, website dan aplikasi.

b) Promosi Penjualan (sales promotion). Promosi penjualan adalah aktivitas pemasaran yang bertujuan untuk meningkatkan target penjualan dalam jangka waktu tertentu dengan menarik perhatian konsumen sebanyak-

banyaknya untuk membeli produk kita, efektivitas penjualan, atau mendorong upaya yang dilakukan oleh tenaga penjualan (sales force). Promosi penjualan yang dilakukan oleh penjual akan menjadi daya tarik tersendiri

untuk mempercepat terjadinya proses pembelian. Bentuk promosi yang bisa dilakukan adalah diskon harga, voucher, pameran, kontes, undian, event khusus, kesepakatan harga, dan premium (tambahan hadiah gratis).

c) Hubungan Masyarakat (public relation). Hubungan masyarakat yaitu upaya komunikasi secara menyeluruh dari suatu perusahaan untuk membangun citra positif yang di dapat dari pengaruh persepsi, opini, keyakinan dan sikap dari berbagai kelompok terhadap perusahaan tersebut. Kelompok yang dimaksud dalam hal ini adalah mereka yang terlibat langsung, memiliki kepentingan dan mempunyai pengaruh terhadap perusahaan dalam kemampuannya untuk mencapai tujuan yang di inginkan.Kelompok tersebut bisa terdiri dari karyawan dan keluarganya, pemegang saham, pelanggan, khalayak/orang-orang yang tinggal di sekitar organisasi, pemasok, perantara, pemerintah dan media massa. Kegiatan-kegiatan yang dapat dilakukan dalam hubungan masyarakat antara lain:

1. Hubungan Komunitas, secara komprehensifhubungan masyarakat melalui program berkelanjutan (sustainability program) di harapkan agar warga masyarakat bisa mendapat citra positif dan meletakkan organisasi sebagai pihak yang peduli terhadap komunitas masyarakat di mana perusahaan itu berada.

2. Hubungan Masyarakat dan Kepentingan Umum, perusahaan harus berusaha menghasilkan citra positif dan memposisikan dirinya sebagai warga negara yang bertanggung jawab dengan menerapkan berbagai program untuk kepentingan umum yang mencakup program identitas perusahaan, seperti perubahan nama dan merek dagang baru yang berfungsi untuk mengubah citra dan identitas perusahaan. Contohnya seperti ulang tahun, pameran dagang, pameran khusus, festival dan acara lainnya.

d) Penjualan Perorangan (personal selling). Personal selling yaitu strategi komunikasi pemasaran yang bisa dikatakan lebih fleksibel karena pihak penjualan bisa langsung berinterkasi dengan calon konsumen untuk memperkenalkan suatu produk, membentuk pemahaman pelanggan terhadap produk dan menyesuaikan penawaran penjualan yang sesuai dengan kebutuhan dan perilaku masing-masing calon pembeli, yang kemudian membuat calon konsumen tersebut akan mencoba dan membelinya. Bentuk promosi yang bisa di lakukan adalah sebagai berikut:

1. Field Selling, yaitu penjualan yang dilakukan di luar perusahaan dengan cara mendatangi secara langsung dari satu rumah kerumah lainnya, dari perusahaan ke 
perusahaan lainnya atau dari tempat kuliner ke tempat kuliner lainnya.

2. Retail Selling, yaitu penjualan yang terfokus pada melayani konsumen yang datang langsung ke perusahaan.

3. Executive Selling, yaitu hubungan yang terjalin antara pemimpin perusahaan dengan pemimpin perusahaan lainnya atau pemerintah dengan tujuan melakukan penjualan.

e) Penjualan Langsung (direct selling). Penjualan langsung merupakan pendekatan pemasaran yang bersifat bebas dalam menentukan saluran distribusi dan/atau komunikasi pemasaran yang memungkinkan perusahaan memiliki strategi sendiri dalam membangun hubungan dengan konsumen. Dalam penjualan langsung tidak ada yang namanya perantara, jadi yang menjalankan penjualan bisa dilakukan secara langsung oleh perusahaan dan konsumen. Dalam penjualan langsung terdapat sejumlah media pemasaran langsung selain melalui surat langsung, antara lain:

1. Brosur, yaitu pendekatan yang bisa dilakukan secara langsung ke calon konsumen tanpa perantara. Brosur biasanya disebarkan langsung dari rumah ke rumah atau bisa di sebarkan juga pada saat ada event atau pameran.

2. Telepon, pemasaran langsung dengan berbasis telepon bisa dilakukan denga dua cara yaitu inbound dan outbound. Inbound telemarketing (telemarketing ke dalam), biasanya dikenal sebagai pelayanan jarak jauh yang biasanya melibatkan penanganan pesanan dan merespon permintaan informasi produk. Sedangkan outbound telemarketing (telemarketing ke luar), biasanya digunakan sebagai penjualan satu langkah (one-step selling), tindak lanjut dan penjualan, memperbesar dan membuat pelanggan jadi aktif.

Tujuan utama dari sebuah industri atau usaha perhotelan yaitu untuk mendapatkan sebanyak mungkin tingkat hunian kamar, namun hal itu tidak terlepas dari kepuasan wisatawan yang akan menyewa atau menghuni kamar tersebut. Pada industri pariwisata, terutama yang bergerak dalam bidang persewaan properti, seperti perhotelan terdapat istilah yang sering disebut dengan room occupancy/hotel occupancy yang diartikan sebagai tingkat hunian kamar hotel.

Sugiarto (2000) berpendapat bahwa, tingkat hunian merupakan suatu keadaan sampai sejauh mana jumlah kamar bisa terjual atau terhuni, jika dibandingkan dengan jumlah seluruh kamar yang sudah tersedia. Jika tingkat hunian kamar dalam suatu hotel itu tinggi, maka hal itu dapat memberikan keuntungan dan penghasilan yang besar bagi hotel tersebut.

Lebih dalam lagi, Damardjati (2006) menjelaskan, tingkat hunian kamar hotel adalah persentase dari kamarkamar yang terisi atau disewakan kepada tamu, dibandingkan dengan jumlah seluruh kamar yang disewakan yang diperhitungkan dalam jangka waktu, misalnya harian, bulanan, atau tahunan.

Sementara itu Sulastiyono (2008) menambahkan bahwa hotel yang berhasil akan terlihat dari tingkat hunian kamarnya. Faktor-faktor yang harus diperhatikan dalam meningkatkan tingkat hunian kamar menurut Suarthana (2006), antara lain lokasi hotel, fasilitas hotel, pelayanan kamar, harga kamar dan promosi.

Dari beberapa pendapat mengenai pengertian okupansi/tingkat hunian kamar maka dapat disimpulkan bahwa okupansi atau tingkat hunian kamar adalah jumlahkamar yang telah terpakai atau tersewakan dari jumlah kamar yang telah tersedia. Tingkat hunian kamar bisa dinyatakan dalam bentuk persentase dari perbandingan kamar yang tersewakan dibandingkan dengan total seluruh kamar yang available atau kamar yang bisa digunakan.

Penelitian terdahulu sebagai bahan rujukan adalah penelitian dari Syahrul Ramadhan (2019) memberikan hasil bahwa penjualan jasa kamar oleh Siwah Hotel mengalami peningkatan karena proses promosi yang gencar dan focus yang dilakukan oleh manajemen, serta profesionalitas yang dilakukan karyawan dalam melayani pengunjung yang datang.

Sedangkan Verayanti (2016) mempunyai kesimpulan penelitian bahwa periklanan berpengaruh positif terhadap tingkat okupansi pada Malabar Hotel Pangandaran, semakin tepat periklanan maka tingkat okupansi pada Malabar Hotel Pangandaran akan semakin naik

Komunikasi pemasaran Hotel RedDoorz Syariah Buduran menggunakan OTA (online travel agent) dan pamflet pada awal pendiriannya, kemudian pada bulan Mei 2019 mereka bekerja sama dengan pihak RedDoorz sehingga strategi pemasaran menjadi semakin luas, mereka juga sudah terhubung dengan tiket.com, serta aplikasi dan website RedDoorz sehingga dapat dijadikan sebagai strategi pemasaran Hotel RedDoorz Syariah Buduran karena jumlah okupansi dapat mencapai sekitar 8 - 9 kamar dari jumlah keselurahan kamar hotel yaitu 12 kamar.

Berdasarkan fenomena diatas maka rumusan masalah dari penelitian ini adalahBagaimana komunikasi pemasaran dalam meningkatkan okupansi kamar di Hotel RedDoorz pada masa pandemi Covid-19?", dengan tujuan penelitian yaitu untuk mendeskripsikan komunikasi pemasaran yang digunakan Hotel RedDoorz Syariah Buduran dalam meningkatkan okupansi kamar. Hasil penelitian ini diharapkan agar dapat memberikan manfaat dalam kajian ilmu komunikasi khususnya yang berkaitan dengan komunikasi pemasaran dalam meningkatkan okupansi kamar hotel dan dapat memberikan sumbangan pemikiran, wawasan atau saran terkait dengan komunikasi pemasaran dalam meningkatkan okupansi kamar di Hotel RedDoorz Syariah Buduran. 


\section{METODE PENELITIAN}

Penelitian ini menggunakan metode penelitian kualitatif dengan pendekatan studi kasus. Menurut Mulyana (2013), studi kasus adalah uraian komprehensif mengenai berbagai aspek seorang individu, suatu organisasi (komunitas), suatu program, atau suatu situasi sosial. Adapun kasus yang dimaksud dalam penelitiani ni yaitu komunikasi pemasaran dalam meningkatkan okupansi kamar di Hotel RedDoorz Syariah Buduran pada masa pandemi Covid-19 sekitar bulan Maret-Agustus 2020. Subjek penelitian ini ditentukan secara purposive yakni pengelola dan pengunjung Hotel RedDoorz Syariah Buduran. Sedangkan objek penelitian ini adalah komunikasi pemasaran dan okupansi Hotel RedDoorz Syariah Buduran. Informan dalam penelitian ini adalah pengelola hotel yang mengetahui kondisi Hotel RedDoorz Syariah Buduran yang berjumlah 3 orang dan ditambah dengan 5 orang pengunjung hotel.

\section{HASIL DAN PEMBAHASAN}

Komunikasi pemasaran yang dilakukan oleh Hotel RedDoorz Syariah Buduran Sidoarjo dalam meningkatkan jumlah okupansi kamar hotel pada masa pandemi yaitu:

1. Periklanan, adalah suatu kegiatan yang digunakan untuk mengkomunikasikan manfaat dari produk yang ditawarkan. Hotel RedDoorz telah melakukan beberapa strategi periklanan dengan menggunakan iklan secara digital yaitu melalui social media (instagram, website dan twitter) dan iklan TV (youtube). Pihak RedDoorz memilih menggunakan iklan secara digital karena pada saat masa pandemi seperti ini iklan tersebut sangat tepat digunakan untuk meningkatkan jumlah okupansi kamar serta untuk mengurangi kontak fisik secara langsung dengan pengunjung..

Adapun sasaran dari iklan tersebut adalah repeater (pengunjung setia RedDoorz) dan new account (konsumen baru). Putu Kreshnamurti, selaku Tim Pemasaran Hotel RedDoorz menjelaskan lebih lanjut bahwa dalam masa pandemi saat ini pihak hotel RedDoorz sedang gencar mempromosikan program sertifikasi "Hygiene Pass" melalui sosial media RedDoorz (Instagram, website dan twitter) dan iklan TV (Youtube). Sertifikasi Hygiene Pass diperoleh dari IAGMI (Ikatan Ahli Gizi Masyarakat Indonesia) untuk standart higiene dan kebersihan hotel RedDoorz sehingga sertifikat tersebut dapat digunakan untuk meyakinkan masyarakat agar tidak ragu dan khawatir untuk menginap di Hotel RedDoorz selama pandemi.

Iklan Hotel RedDoorz Syariah Buduran mendapat apresiasi dari pengunjung dimana semua informan tersebut pernah melihat iklan Hotel RedDoorz dan ratarata mereka melihat iklan tersebut di media sosial seperti youtube, website, twitter, dan Instagram, bahwa media iklan tersebut sangatlah tepat digunakan selama pandemi karena dapat meningkatkan jumlah okupansi kamar serta untuk mengurangi kontak fisik secara langsung dengan pengunjung.

2. Promosi penjualan. Promosi adalah aktivitas pemasaran yang bertujuan untuk meningkatkan target penjualan dalam jangka waktu tertentu dengan menarik perhatian konsumen sebanyak-banyaknya untuk membeli produk kita, efektivitas penjualan, atau mendorong upaya yang dilakukan oleh tenaga penjualan (sales force).

Selain melakukan promosi melalui iklan secaradigital, Pihak Hotel RedDoorz juga melakukan promosi penjualan dengan membagikan voucher kepadapengunjung. Namun promosi tersebut juga dilakukan saat sebelum masa pandemi sebagai media pemasarannya. Promosi tersebut dipilih karena voucher dapat membuat masyarakat mudah untuk mengingat RedDoorz. Masyarakat dapat mengingat RedDoorz ketika sedang berpergian dan membutuhkan hotel budget untuk menginap karena mempunyai voucher RedDoorz.

Pemberian voucher selalu dilakukan pada saat pengunjung akan check out dari hotel, setelah menginap beberapa hari. Ini merupakan bentuk promosi yang cukup efektif, sehingga pengunjung bisa kembali menginap di hotel ini. Voucher adalah media pemasaran yang cukup diminati oleh masyarakat, karena merupakan media pemasaran yang mudah digunakan dan mudah disebarluaskan.

Sedangkan untuk pameran, manajemen Hotel RedDoorz Syariah Buduran tidak pernah mengadakannya, hal ini karena pihak Hotel RedDoorz selalu mengadakan promosi-promosi. Contoh event yang dilakukan pada masa pandemi yaitu Batik Oktofest yang diadakan di atrium utama ITC Mega Grosir - Surabaya. Disana pihak RedDoorz membagikan beberapa voucher dan brosur kepada para pengunjung yang hadir di event tersebut.

Dengan uraian diatas, Hotel RedDoorz Syariah Buduran telah melakukan promosi penjualan yaitu voucher diskon dan event-event untuk menarik minat pengunjung dan memberikan pemahaman hotel ini sudah terjamin keamanannya serta selalu menerapkan protokol kesehatan yang ketat. Pengunjung yang telahmendapatkan voucher bisa mempromosikan keberadaan hotel ini karena kelebihan-kelebihan tersebut.

3. Hubungan Masyarakat. Hubungan masyarakat adalah upaya komunikasi secara menyeluruh dari suatu perusahaan untuk membangun citra positif yang di dapat dari pengaruh persepsi, opini, keyakinan dan sikap dari berbagai kelompok terhadap perusahaan tersebut.

Selain periklanan dan promosi penjualan Hotel RedDoorz Syariah Buduran juga menggunakan strategi untuk menarik daya minat pengunjung melalui hubungan 
masyarakat seperti mengadakan acara ulang tahun, pameran dagang, pameran khusus, festival dan acara lainnya.

Acara ulang tahun Hotel RedDoorz Syariah Buduran yang pertama pada saat bulan November 2019, dengan mengundang masyarakat sekitar dan anak dari yayasan yatim piatu untuk mengikuti acara syukuran, yang bertujuan untuk menjalin hubungan baik dan mendapatkan citra positif. Sedangkan untuk pameran, mengikuti manajemen hotel RedDoorz.

4. Penjualan Perorangan. Personal selling adalah strategi komunikasi pemasaran yang bisa dikatakan lebih fleksibel karena pihak penjualan bisa langsung berinterkasi dengan calon konsumen untuk memperkenalkan suatu produk, membentuk pemahaman pelanggan terhadap produk dan menyesuaikan penawaran penjualan yang sesuai dengan kebutuhan dan perilaku masing-masing calon pembeli, yang kemudian membuat calon konsumen tersebut akan mencoba dan membelinya.

Hotel RedDoorz Syariah Buduran menggunakan penjualan perorangan untuk memperoleh konsumen dengan mudah karena kegiatan yang dilakukan dapat membuat masyarakat merasakan adanya program tersebut. Manajemen hotel sering melakukan promosi di tempat-tempat kuliner dan event-event dengan membagikan voucher di acara tersebut. Hal ini berarti bahwa penjualan perorangan di Hotel RedDoorz Syariah Buduran sudah sesuai dengan teori penjualan perorangan yaitu Field Selling yang penjualannya dilakukan di luar Hotel RedDoorz Syariah Buduran dengan cara membagikan voucher di tempat kuliner dan Retail Selling yang penjualannya berfokus melayani konsumen yang datang langsung ke Hotel RedDoorz Syariah Buduran.

5. Penjualan langsung, merupakan pendekatan pemasaran yang bersifat bebas dalam menentukan saluran distribusi dan/atau komunikasi pemasaran yang memungkinkan perusahaan memiliki strategi sendiri dalam membangun hubungan dengan konsumen.

Dalam penjualan langsung tidak ada yang namanya perantara, jadi yang menjalankan penjualan bisa dilakukan secara langsung oleh perusahaan dan konsumen. Hotel RedDoorz Syariah Buduran gencar melakukan penjualan dengan telesales atau telemarketing (menelpon calon konsumen) dan membagikan brosur kepada calon konsumen pada saat mengadakan join event dan tidak pernah membagikan brosur dijalan - jalan atau tempat umum lainnya. Kecuali pada saat sebelum ada pandemi, manajemen hotel juga membagikan voucher di CFD.
Uraian di atas menjelaskan bahwa Hotel RedDoorz Syariah Buduran telah melakukan kegiatan komunikasi pemasaran yaitu periklanan, promosi penjualan, hubungan masyarakat, penjualan perorangan dan penjualan langsung, dalam masa pandemi covid 19. Kegiatan ini terutama berhubungan dengan penyebaran informasi menggunakan iklan secara digital melalui media sosial seperti media (instagram, website dan twitter) dan iklan TV (youtube), voucher diskon, promosi melalui eventevent, melibatkan masyarakat pada saat event ulang tahun hotel, dan telesales serta telemarketing.

Hasil ini sesuai dengan kesimpulan penelitian Mumtazah dkk (2020), bahwa dalam meningkatkan brandloyalty, CV Khairil Tour \& Travel melakukan strategi komunikasi pemasaran melalui media sosial diantaranya Instagram, Facebook, WhatsUp dan Youtube dengan konten promosi yaitu pessan bergambar dalam bentuk poster digital yang berisi foto produk (obyek wisata), informasi waktu perjalanan, kontak person, dan tambahan inforrmasi mengenai protokol pencegahan Covid-19 yang tetap diperhatikan.

Penelitian lain yang juga menghasilkan kesimpulan yang sama adalah penelitian Rulandari dkk (2020), bahwa dalam menghadapi masa New Normal saat ini, pelaku UMKM menggunakan strategi komunikasi pemasaran digital, strategi soft selling dan tetap melakukan penjualan melalui pasar tradisional. Dengan ketiga teknik ini, para pelaku UMKM bisa bertahan.

Berbagai teknik kegiatan komunikasi pemasaran pada masa pandemic terus menerus dilakukan pihak manajemen hotel, tetapi upaya untuk meningkatkan jumlah okupansi pada masa pandemi covid 19 belum menunjukan hasil secara signifikan atau belum sesuai harapan artinya terdapat peningkatan meskipun sedikit dari awal adanya pandemi Covid - 19. Pengunjung Hotel RedDoorz Syariah Buduran masih belum sebanyak saat sebelum adanya pandemi. Hal ini bisa dilihat dari data terakhir tingkat okupansi kamar.

\section{KESIMPULAN}

Adapun kesimpulan yang dapat diberikan dari hasil analisis dan pembahasan mengenai komunikasi pemasaran yang dilakukan untuk meningkatkan okupansi kamar di hotel RedDoorz Syariah Buduran pada masa pandemi Covid 19 adalah Periklanan dengan menggunakan iklan secara digital melalui media sosial seperti media ( instagram, website dan twitter ) dan iklan TV ( youtube ), promosi penjualan melalui pembagian voucher diskon kepada pengunjung dan menggadakan event-event khusus, hubungan masyarakat dengan mengudang masyarakat sekitar pada saat acara ulang tahun hotel, penjualan perorangan melalui pembagian voucher di tempat kuliner dan pengunjung yang datang langsung ke hotel, serta penjualan langsung dengan melakukan promosi melalui telepon kepada calon konsumen dan membagikan bro- 
sur ketika mengadakan event.

Tingkat okupansi kamar di hotel RedDoorz Syariah Buduran belum menunjukkan peningkatan yang signifikan. Pengunjung Hotel RedDoorz Syariah Buduran masih belum sebanyak saat sebelum adanya pandemi, namun sedikit meningkat dari awal adanya pandemi Covid - 19. Dan untuk kedepannya, sebaiknya pihak hotel RedDoorz Syariah Buduran lebih sering melakukan promosi di sosial media, memperbanyak diskon dan promo - promo menarik agar masyarakat lebih tertarik untuk menginap di hotel RedDoorz Syariah Buduran.

\section{UCAPAN TERIMAKASIH}

Terimakasih kami sampaikan pada civitas akademik di Universitas Muhammadiyah Sidoarjo dan pengelolah jurnal Kanal yang telah bersedia menerima dan mempublikasikan naskah kami.

\section{REFERENSI}

Assauri, Sofjan. (2013). Manajemen Pemasaran. Jakarta: PT Raja Grafindo Persada.

Damardjati, R.S. (2006). Istilah-istilah Dunia Pariwisata. Jakarta: PT. Pradnya Paramita.

Diayudha, Lanang. (2020). Industri Perhotelan di Indonesia pada Masa Pandemi. Journal FAME. 3 (1), 01-56.

Mumtazah, A., Novalia, dan Emilia, R. I. (2020). Strategi Komunikasi Pemasaran Digital untuk Meningkatkan Brand Loyalty pada Perusahaan Travel di Masa Pandemi Covid-19 (Studi Kasus pada CV. Khairil Tour \& Travel) https://repository.bsi.ac.id/index.php/repo/viewitem/26055 (Accessed on 12 August 2020).

Purba, Amir. (2006). Pengantar Ilmu Komunikasi. Medan: Pustaka Bangsa.

Ramadhan, Syahrul (2019) Promosi Siwah Hotel dalam Meningkatkan Pengunjung Di Banda Aceh.Skripsi. Fakultas Dakwah \& Komunikasi Universitas Islam Negeri Ar - Raniry Darussalam, Banda Aceh.

Rulandari, N., Ramhawati, N. F., Nurbaiti, D. (2020). Strategi Komunikasi Pemasaran Usaha Mikro Kecil dan Menengah pada Era New Normal. Prosiding Seminar Stiami, 7(2), 21-28.

Stanton, William J. (2007). Manajemen Pemasaran. Jakarta: Penerbit Erlangga.

Suarthana (2006). Manajemen Perhotelan Edisi Kantor Depan. Kuta Utara: Mapindo.

Sugiarto, Endar. (2004). Hotel Front Office Administration. Jakarta: Gramedia Pustaka Utama.

Sulastiyono, Agus. (2008). Manajemen Penyelenggaraan Hotel. Cetakaan keenam. Bandung: Alfabeta.

Verayanti. (2016). Pengaruh Periklanan dan Kebijakan Harga Terhadap Peningkatan Tingkat Okupansi Hotel. Jurnal Ilmu Manajemen, 3 (1), 163-165.

Conflict of Interest Statement: The authors declare that the research was conducted in the absence of any commercial or financial relationships that could be construed as a potential conflict ofinterest.

Copyright (C) 2021 Rochmaniah, et.al. This is an open-access article distributed under the terms of the Creative Commons Attribution License (CC BY). The use, distribution or reproduction in other forums is permitted, provided the original author(s) and the copyright owner(s) are credited and that the original publication in this jour-nal is cited, in accordance with accepted academic practice. No use, distribution or reproduction is permitted which does not comply with these terms. 